\title{
Association of Serum C-Reactive Protein Levels With Lupus Disease Activity in the Absence of Measurable Interferon- $\alpha$ and a C-Reactive Protein Gene Variant
}

Helena Enocsson, Christopher Sjöwall, Alf Kastbom, Thomas Skogh, Maija-Leena Eloranta,

Lars Rönnblom and Jonas Wetterö

\section{Linköping University Post Print}

\section{Tweet}

N.B.: When citing this work, cite the original article.

Original Publication:

Helena Enocsson, Christopher Sjöwall, Alf Kastbom, Thomas Skogh, Maija-Leena Eloranta, Lars Rönnblom and Jonas Wetterö, Association of Serum C-Reactive Protein Levels With Lupus Disease Activity in the Absence of Measurable Interferon- $\alpha$ and a C-Reactive Protein Gene Variant, 2014, Arthritis \& rheumatology (Hoboken, N.J.), (66), 6, 1568-1573.

http://dx.doi.org/10.1002/art.38408

Copyright: Wiley Online Library

http://onlinelibrary.wiley.com/journal/10.1002/\%28ISSN\%292326-5205

Postprint available at: Linköping University Electronic Press

http://urn.kb.se/resolve?urn=urn:nbn:se:liu:diva-105501 


\title{
Association of serum C-reactive protein levels with lupus disease activity in the absence of measurable interferon- $a$ and a $\mathrm{C}$-reactive protein gene variant
}

Running head: CRP reflects SLE activity in the absence of IFN $\alpha$ and a CRP gene variant

\author{
${ }^{1}$ Helena Enocsson, ${ }^{1}$ Christopher Sjöwall, ${ }^{1}$ Alf Kastbom, ${ }^{1}$ Thomas Skogh, \\ ${ }^{2}$ Maija-Leena Eloranta, ${ }^{2}$ Lars Rönnblom, ${ }^{1}$ Jonas Wetterö
}

Affiliations: ${ }^{1}$ Helena Enocsson, MSc, Christopher Sjöwall, MD PhD, Alf Kastbom MD PhD, Thomas Skogh, MD PhD, Jonas Wetterö, PhD: Rheumatology, Department of Clinical and Experimental Medicine, Linköping University, Linköping, Sweden. ${ }^{2}$ Lars Rönnblom, MD PhD, Maija-Leena Eloranta, PhD: Department of Medical Sciences, Science for Life Laboratory, Uppsala University, Uppsala, Sweden

Grant support: The Swedish Research Council, the County Council of Östergötland Research Foundations, the Swedish Society for Medicine, the Swedish Society against Rheumatism, the Swedish Society for Medical Research, the King Gustaf V 80-year Foundation, Lions (Linköping) Foundation, and the Ingrid Svensson, Siv Olsson, Bröderna Karlsson, Gunnar Trosell, Magnus Bergvall, Sigurd and Elsa Golje, Professor Nanna Svartz, Knut and Alice Wallenberg, and Torsten Söderberg Foundations.

Address for reprint requests: Helena Enocsson (corresponding author), AIR/Rheumatology, Patologihuset plan 10, Department of Clinical and Experimental Medicine (IKE), Linköping University, SE-581 85 Linköping, Sweden. Phone: +46 (0)10 1034611, Fax number: +46 (0)13 132257, e-mail: helena.enocsson@liu.se 


\begin{abstract}
Objectives: The type I interferon (IFN) system is important in the pathogenesis of systemic lupus erythematosus (SLE). We previously demonstrated an inhibitory effect of IFN $\alpha$ on interleukin 6 (IL-6) induced C-reactive protein (CRP) in vitro, hypothetically explaining the poor correlation between disease activity and CRP levels in SLE. Herein we investigated disease activity, IL-6 and CRP in relation to a CRP gene polymorphism and IFN $\alpha$.
\end{abstract}

Methods: Sera from 155 SLE patients and 100 controls were analyzed for CRP. Patients were genotyped for a $C R P$ single nucleotide polymorphism (rs1205) associated with low CRP levels. Serum IFN $\alpha$ and IL-6 was quantified by immunoassays. Clinical disease activity was assessed by SLE disease activity index 2000 (SLEDAI-2K).

Results: CRP levels were increased in SLE patients compared to controls, but were not associated with SLEDAI-2K or IL-6 levels. However, exclusion of patients carrying at least one rs1205 minor allele revealed an association between disease activity and CRP levels $(p=0.005)$. We found a strong association between disease activity and CRP levels $(p<0.0005)$ when patients with measurable IFN $\alpha$ as well as the minor allele of rs 1205 where excluded from the analysis. Similarly, when patients with raised IFN $\alpha$ and/or the rs1205 polymorphism were excluded, IL-6 associated with CRP levels.

Conclusions: The present study demonstrates that serum IFN $\alpha$ as well as $C R P$ genotype affects the CRP response in SLE patients. Lack of correlation between serum levels of CRP and disease activity could therefore be explained by activation of the type I IFN system and polymorphisms in the $C R P$ gene. 
Systemic lupus erythematosus (SLE) is an inflammatory disease characterized by multi-organ involvement, circulating autoantibodies (most notably antinuclear antibodies, ANA), increased levels of interferon $\alpha($ IFN $\alpha)$ and/or expression of IFN $\alpha$ inducible genes, the "type I IFN signature" [1]. Despite large efforts, we still lack reliable disease activity markers covering all disease phenotypes of SLE. Instead, an array of clinical data and biomarkers are used to evaluate organ involvement and disease activity [2]. The acute phase protein $\mathrm{C}$ reactive protein $(\mathrm{CRP})$ is widely used to monitor inflammation in diseases such as rheumatoid arthritis and bacterial infections, but is not a reliable inflammation marker in SLE as the serum levels often remain low despite high disease activity coinciding with raised levels of interleukin (IL)-6 [3-7]. Hepatocytes are the main producers of human CRP, and the most important inducer of CRP transcription in primary cells is IL-6 [8-11]. Baseline and acute phase levels of CRP are also dependent on polymorphisms in the CRP gene [4].

CRP may contribute to an anti-inflammatory elimination of cell debris due to its opsonizing properties and ability to bind nuclear components $[11,12]$ and SLE patients would therefore probably benefit from an adequate CRP elevation during disease flares. Apoptotic cells that are not eliminated immediately will expose nuclear components on their surface which in turn can induce immune reactions with autoantibody production and formation of immune complexes that can deposit in tissues and cause further inflammation [12].

As in SLE flares, CRP is often low during viral infections. The difference in CRP response between viral and bacterial infections makes CRP analysis a useful tool to discriminate between these two types of infection. Interestingly, viral infections induce IFN $\alpha$ production in order to fight the viral replication and activate an appropriate immune response [13]. We previously showed that IFN $\alpha$ inhibits IL-6 induced CRP production by human hepatocytes in 
vitro [10], and based on this we hypothesized that raised levels of IFN $\alpha$ contribute to an inadequately low CRP response during SLE flares and viral infections, by uncoupling the correlation between IL-6 and CRP. Hence, we now investigated the circulating levels of CRP, IL-6 and IFN $\alpha$ in serum from SLE patients. Since genetic variation of the $C R P$ gene may influence CRP levels, we furthermore analyzed the SNP rs1205 which has been associated with low basal and acute phase levels of CRP [4, 14-20], and to the risk of developing SLE $[21,22]$.

\section{PATIENTS AND METHODS}

\section{Patients and controls}

A total of 155 SLE patients were included from KLURING (Swedish acronym for "clinical lupus register in northeastern Gothia") i.e. a prospective follow-up project at the Rheumatology clinic, Linköping university hospital, Sweden [23]. Informed consent was obtained from all subjects and the study protocol was approved by the Regional ethics committee in Linköping (M75-08/2008). Prevalent (92\%) as well as incident cases (8\%) were recruited consecutively during 2008-2011. All patients met the 1982 American college of rheumatology (ACR) classification criteria [24]. Body mass index (BMI) and SLE International collaborating clinics (SLICC)/ACR damage index [25] was registered at blood sampling. Disease activity was registered according to the SLE disease activity index 2000 (SLEDAI-2K) [26]. Of the 155 patients, 138 (89\%) were females and 143 (92\%) were Caucasians. The patients were treated as follows: 58 (37\%) were prescribed antimalarials (AM) alone, 48 (31\%) were medicated with disease-modifying anti-rheumatic drugs (DMARDs) \pm AM, and 105 (68\%) were treated with prednisolone. Further patient characteristics are shown in Table 1. 
One hundred healthy blood donors ( $50 \%$ females) served as control subjects. The mean age was 45.8 years, ranging from 22 to 70 years of age.

\section{CRP and cytokine analyses}

Venous blood was drawn from each individual and serum was prepared and kept at $-70^{\circ} \mathrm{C}$ until analyzed. High sensitivity CRP (detection limit $0.12 \mathrm{mg} / \mathrm{L}$ ) was analyzed by turbidimetry at the routine clinical chemistry laboratory at Linköping university hospital. IFN $\alpha$ (detection limit $1 \mathrm{U} / \mathrm{mL}$ ) was measured in sera from SLE patients by a dissociationenhanced lanthanide fluorescent immunoassay at Uppsala university, Sweden, as previously described [27]. IL-6 (detection limit $0.64 \mathrm{pg} / \mathrm{mL}$ ) was analyzed by a high sensitivity multiplex magnetic bead assay (Milliplex, Millipore, Solna, Sweden) according to the manufacturer's instruction. Non-detectable levels of cytokines or CRP were given half the value of the detection limit.

\section{Genotyping}

Genomic DNA was obtained from whole blood samples using QIAamp DNA Blood Midi Kit (Qiagen, Hilden, Germany). The SNP rs1205 was genotyped by using the Golden Gate Assay (Illumina Inc. San Diego, CA). 


\section{Statistical analyses}

Chi-square (Fisher's exact test) was used when categorical variables were analyzed. MannWhitney's test was used to assess differences in cytokine or CRP levels between patients and controls as well as between patient groups. The associations of CRP and disease activity or IL-6 were evaluated using multiple linear regression models with $\log 10$-transformed CRP as the response variable. Residual plots showed that the residuals were randomly distributed around zero suggesting that the multiple linear regression models were appropriate. P-P plots also showed that the residuals were normally distributed (data not shown). Because of age $[28,29]$ and body mass index (BMI)-dependent variations of CRP levels $[30,31]$, these were included as independent variables in multiple linear regression analyses. All regression analyses were also performed with adjustment for prednisolone dose but since it did not influence CRP levels significantly, and no other significance arose or disappeared due to prednisolone adjustment we chose not to adjust for this.

Two-tailed $\mathrm{p}$-values of $<0.05$ were considered significant. Statistical analyses were performed with SPSS Statistics 21 (IBM, Armonk, NY).

\section{RESULTS}

\section{Serum CRP levels are elevated in SLE patients, but not related to disease activity}

CRP levels were significantly higher in SLE patients (median; $\mathrm{mdn}=2.11 \mathrm{mg} / \mathrm{L}$ ) compared to healthy controls $(\mathrm{mdn}=0.49 \mathrm{mg} / \mathrm{L}), \mathrm{p}<0.0005$. There was however no significant difference in CRP levels between patients with high disease activity, defined as SLEDAI $\geq 6$ ( $n=24$, $\mathrm{mdn}=2.00 \mathrm{mg} / \mathrm{L}$ ) and patients with no or low disease activity (SLEDAI $<6, \mathrm{n}=131$, $\mathrm{mdn}=2.52 \mathrm{mg} / \mathrm{L})$ (Figure 1). 


\section{Effects of the SNP rs1205 and IFN $\alpha$ on CRP levels}

Comparing CRP levels between SLE patients homozygous for the major allele $(G)(n=73)$ with SLE patients heterozygous or homozygous $(n=82)$ for the minor allele $(A$; associated with lower CRP levels [4]) revealed significantly lower CRP levels among patients with the minor allele $(\mathrm{mdn}=1.35 \mathrm{mg} / \mathrm{L}), \mathrm{p}=0.045$ (Table 2). A significant negative impact of the minor allele of rs1205 on logCRP levels was also found after adjusting for age and BMI in a regression analysis $(\mathrm{p}=0.046)$. Genotype frequencies did not deviate from the HardyWeinberg equilibrium ( $\mathrm{p}=0.663$ by chi-square test). A comparison of CRP levels between patients with ( $\mathrm{n}=36)$ and without $(\mathrm{n}=119)$ measurable levels of IFN $\alpha(\geq 1 \mathrm{U} / \mathrm{mL})$ implied lower median CRP levels among patients with detectable levels of IFNa (1.81 vs. $2.14 \mathrm{mg} / \mathrm{L})$ although this difference was not statistically significant.

\section{Association between serum CRP and SLEDAI-2K or serum IL-6}

Based on previous in vitro findings concerning an inhibitory effect of IFN $\alpha$ on IL-6 induced CRP production [10], we performed a multiple linear regression analysis to investigate if CRP is reflected by clinical disease activity (SLEDAI-2K) or IL-6 levels among patients without detectable IFN $\alpha$ levels $(<1 \mathrm{U} / \mathrm{mL})$ and/or the rs1205 polymorphism (Table 3$)$. Neither SLEDAI-2K, nor IL-6 were associated with logCRP among all patients $(\mathrm{n}=155)$, but a significant association between $\log \mathrm{CRP}$ and IL-6 $(\mathrm{p}=0.001)$ was found when excluding patients with IFN $\alpha \geq 1 \mathrm{U} / \mathrm{mL}$. Among patients homozygous for the major allele of rs 1205 , both SLEDAI-2K $(\mathrm{p}=0.005)$ and IL-6 $(\mathrm{p}=0.001)$ were associated with $\log \mathrm{CRP}$. When limiting the patient group to those homozygous for the major allele of rs1205 and with nonmeasurable IFN $\alpha(<1 \mathrm{U} / \mathrm{mL})(\mathrm{n}=57)$, both SLEDAI-2K $(\mathrm{p}<0.0005)$ and IL-6 $(\mathrm{p}=0.001)$ were strongly associated with $\log \mathrm{CRP}$. The 57 patients without detectable IFN $\alpha$ and CRP-lowering rs1205 variants were not significantly different from the other patients with regard to clinical 
features such as SLEDAI-2K, number of fulfilled ACR criteria, specific ACR criteria or SLICC/ACR damage index (not shown).

\section{The rs1205 polymorphism, CRP and IFN $\alpha$ in relation to disease phenotypes}

Significantly higher levels of CRP were found in patients meeting the ACR criteria of serositis $(\mathrm{mdn}=2.98 \mathrm{mg} / \mathrm{L})$ compared to patients not fulfilling this criteria $(\mathrm{mdn}=1.37 \mathrm{mg} / \mathrm{L})$, $\mathrm{p}=0.007$. Patients fulfilling the photosensitivity criterion had significantly lower levels of CRP (mdn=1.49 mg/L) than patients without this criterion $(\mathrm{mdn}=2.70 \mathrm{mg} / \mathrm{L}), \mathrm{p}=0.015 . \mathrm{IFN \alpha}$ was significantly higher in patients fulfilling the criteria of malar rash $(\mathrm{p}=0.023)$, renal disorder $(p=0.006)$, hematologic disorder $(p=0.008)$, immunologic disorder $(p=0.027)$ and neurologic disorder $(\mathrm{p}<0.0005)$. Mdn values of IFN $\alpha$ were $0.5 \mathrm{U} / \mathrm{mL}$ regardless of fulfilling the above mentioned criteria, except for neurologic disorder were the mdn value was 4.22 $\mathrm{U} / \mathrm{mL}$ for patients fulfilling this criterion. There was no significant association between rs1205 genotypes and ACR criteria.

\section{DISCUSSION}

In the present study we found an association between SLE disease activity and CRP levels in patients without detectable IFN $\alpha$ levels in serum, and without a genetic variant associated with low CRP levels. We also found an association between IL-6 and CRP in these patients. These observations, together with the previously reported mechanistic evidence [10], indicate an interfering effect of IFN $\alpha$ on IL-6-induced CRP production and pronounced effects of the $C R P$ lowering genetic variant of rs1205 on CRP levels. The absence of correlation between IL-6 and CRP [3, 32-34] and the poor performance of CRP as an inflammation marker in SLE $[5,7]$ could therefore be due to a heterogeneous SLE population with regard to IFN $\alpha$ and CRP genetics. 
We found elevated levels of CRP in patients with ongoing and/or a history of serositis (ACR criterion 6) and higher levels of IFN $\alpha$ in patients with renal, neurologic and hematologic involvement (ACR criteria 7, 8 and 9), essentially consistent with previous studies [35-38]. Interestingly, CRP and IFN $\alpha$ levels, respectively, were thus raised in patients with disparate disease phenotypes.

CRP, an opsonin with affinity for phosphocholine (PC) exposed on apoptotic cells, can activate the classical complement pathway. This results in further opsonization, but typically not to membrane attack complex formation. Thereby, CRP contributes to a non-inflammatory clearance of dying cells $[12,39]$. In addition, CRP can bind to several nuclear components such as small nuclear ribonucleoproteins (snRNP), dsDNA and histones [11], all of which are known targets for autoantibodies in SLE. It is therefore tempting to speculate that CRP could protect from SLE by interrupting the "vicious circle" of autoantibody production, immune complex formation and tissue inflammation. In support of these assumptions, studies show beneficial effects of CRP-treatment in murine SLE models [40, 41] and delay of SLE onset in lupus-prone mice expressing a human CRP transgene [42], although conflicting results have been published [43]. Further, CRP was recently shown to inhibit immune complex induced IFN $\alpha$-production by plasmacytoid dendritic cells [44], and certain CRP-lowering genetic variants and haplotypes of the $C R P$ gene are more frequent among SLE patients $[22,45,46]$. Given these observations, it is of great importance to understand the regulation of CRP production. This is also important in relation to the emerging anti-IFN $\alpha$ therapy, which could hypothetically lead to a normalized and beneficial CRP response. 
An association between genetic variations in the $C R P$ gene and serum CRP levels was first described in 2002 by Szalai et al [47], and a large number of SNPs have now been described, but only a few have consistently been related to CRP levels [4]. In the present study we evaluated rs1205, a SNP located in the 3' untranslated region of the CRP gene. This SNP has been associated with low CRP in numerous studies [4, 14-20] and is associated with SLE susceptibility and ANA levels [22]. Further, rs1205 was the SNP with strongest independent association to low CRP levels in a Bayesian meta-analysis [48]. Despite a relatively small number of patients, we found significantly lower levels of CRP in patients with one or two rare alleles of rs1205. Excluding these patients from the regression analysis revealed a highly significant association of IL-6 or SLEDAI with CRP levels, indicating that gene polymorphisms can be a major reason for a modest CRP response during SLE flares. Yet, SLE patients mount an apparently normal CRP response during bacterial infections [6, 35, 49] which could suggest a multifaceted rather than a single explanation [4].

It has been hypothesized that CRP, like complement, is consumed by the increased apoptosis rate, but the consumption of CRP appears to be normal in SLE patients [50]. Further, the antiCRP antibodies found in SLE patients do not correlate with CRP levels and these autoantibodies are directed against monomeric CRP, but not against the pentameric circulating form [51]. Hence, it is likely that the inappropriately low serum CRP during SLE flares is due to a decreased production, rather than increased clearance.

To conclude, the interaction between different pro-inflammatory molecules as well as the patients' genetic setup needs to be considered when evaluating biomarkers in lupus. The findings in this study indicate that $C R P$ genetic variants and raised serum IFN $\alpha$ at least partly underlie the poor performance of CRP as a disease activity marker in SLE patients. 


\section{ACKNOWLEDGEMENTS}

The authors thank research nurse Marianne Peterson and the clinicians at Linköping university hospital. Anne Trönnberg at Uppsala university is acknowledged for help with IFN $\alpha$ measurements. Karl Wahlin at Linköping university and Andrei Alexsson at Uppsala university are appreciated for advice on statistical analyses. 


\section{REFERENCES}

1. Rönnblom L, Alm GV, Eloranta ML. The type I interferon system in the development of lupus. Semin Immunol 2011;23:113-21.

2. Ahearn JM, Liu CC, Kao AH, Manzi S. Biomarkers for systemic lupus erythematosus. Transl Res 2012;159:326-42.

3. Gabay C, Roux-Lombard P, de Moerloose P, Dayer JM, Vischer T, Guerne PA. Absence of correlation between interleukin 6 and C-reactive protein blood levels in systemic lupus erythematosus compared with rheumatoid arthritis. J Rheumatol 1993;20:815-21.

4. Rhodes B, Furnrohr BG, Vyse TJ. C-reactive protein in rheumatology: biology and genetics. Nat Rev Rheumatol 2011;7:282-9.

5. Rezaieyazdi Z, Sahebari M, Hatef MR, Abbasi B, Rafatpanah H, Afshari JT et al. Is there any correlation between high sensitive CRP and disease activity in systemic lupus erythematosus? Lupus 2011;20:1494-500.

6. Pepys MB, Lanham JG, De Beer FC. C-reactive protein in SLE. Clin Rheum Dis 1982;8:91-103.

7. Barnes EV, Narain S, Naranjo A, Shuster J, Segal MS, Sobel ES et al. High sensitivity C-reactive protein in systemic lupus erythematosus: relation to disease activity, clinical presentation and implications for cardiovascular risk. Lupus 2005; 14:576-82.

8. Zhang D, Sun M, Samols D, Kushner I. STAT3 participates in transcriptional activation of the C-reactive protein gene by interleukin-6. J Biol Chem 1996;271:9503-9.

9. Marnell L, Mold C, Du Clos TW. C-reactive protein: ligands, receptors and role in inflammation. Clin Immunol 2005;117:104-11.

10. Enocsson H, Sjöwall C, Skogh T, Eloranta ML, Rönnblom L, Wetterö J. Interferonalpha mediates suppression of C-reactive protein: Explanation for muted C-reactive protein response in lupus flares? Arthritis Rheum 2009;60:3755-60.

11. Du Clos TW. Pentraxins: Structure, Function, and Role in Inflammation. ISRN Inflamm 2013;379040:1-22.

12. Gershov D, Kim S, Brot N, Elkon KB. C-Reactive protein binds to apoptotic cells, protects the cells from assembly of the terminal complement components, and sustains an antiinflammatory innate immune response: implications for systemic autoimmunity. J Exp Med 2000;192:1353-64.

13. Samuel CE. Antiviral actions of interferons. Clin Microbiol Rev 2001;14:778-809.

14. Suk Danik J, Chasman DI, Cannon CP, Miller DT, Zee RY, Kozlowski P et al. Influence of genetic variation in the $\mathrm{C}$-reactive protein gene on the inflammatory response during and after acute coronary ischemia. Ann Hum Genet 2006;70:705-16.

15. Kong H, Qian YS, Tang XF, Zhang J, Gao PJ, Zhang Y et al. C-reactive protein (CRP) gene polymorphisms, CRP levels and risk of incident essential hypertension: findings from an observational cohort of Han Chinese. Hypertens Res 2012;35:101923. 
16. Bolton CE, Schumacher W, Cockcroft JR, Timpson NJ, Smith GD, Gallacher J et al. The CRP genotype, serum levels and lung function in men: the Caerphilly Prospective Study. Clin Sci (Lond) 2011;120:347-55.

17. Miller DT, Zee RY, Suk Danik J, Kozlowski P, Chasman DI, Lazarus R et al. Association of common CRP gene variants with CRP levels and cardiovascular events. Ann Hum Genet 2005;69:623-38.

18. Veen G, Giltay EJ, van Vliet IM, Derijk RH, Klaassens ER, van Pelt J et al. Creactive protein polymorphisms are associated with the cortisol awakening response in basal conditions in human subjects. Stress 2011;14:128-35.

19. Rhodes B, Meek J, Whittaker JC, Vyse TJ. Quantification of the genetic component of basal C-reactive protein expression in SLE nuclear families. Ann Hum Genet 2008;72:611-20.

20. Flores-Alfaro E, Fernandez-Tilapa G, Salazar-Martinez E, Cruz M, Illades-Aguiar B, Parra-Rojas I. Common variants in the CRP gene are associated with serum Creactive protein levels and body mass index in healthy individuals in Mexico. Genet Mol Res 2012;11:2258-67.

21. Edberg JC, Wu J, Langefeld CD, Brown EE, Marion MC, McGwin G, Jr. et al. Genetic variation in the CRP promoter: association with systemic lupus erythematosus. Hum Mol Genet 2008;17:1147-55.

22. Russell AI, Cunninghame Graham DS, Shepherd C, Roberton CA, Whittaker J, Meeks J et al. Polymorphism at the C-reactive protein locus influences gene expression and predisposes to systemic lupus erythematosus. Hum Mol Genet 2004;13:137-47.

23. Enocsson H, Wetterö J, Skogh T, Sjöwall C. Soluble urokinase plasminogen activator receptor levels reflect organ damage in systemic lupus erythematosus. Transl Res 2013;162:287-96.

24. Tan EM, Cohen AS, Fries JF, Masi AT, McShane DJ, Rothfield NF et al. The 1982 revised criteria for the classification of systemic lupus erythematosus. Arthritis Rheum 1982;25:1271-7.

25. Gladman D, Ginzler E, Goldsmith C, Fortin P, Liang M, Urowitz M et al. The development and initial validation of the Systemic Lupus International Collaborating Clinics/American College of Rheumatology damage index for systemic lupus erythematosus. Arthritis Rheum 1996;39:363-9.

26. Gladman DD, Ibanez D, Urowitz MB. Systemic lupus erythematosus disease activity index 2000. J Rheumatol 2002;29:288-91.

27. Cederblad B, Blomberg S, Vallin H, Perers A, Alm GV, Rönnblom L. Patients with systemic lupus erythematosus have reduced numbers of circulating natural interferonalpha-producing cells. J Autoimmun 1998;11:465-70.

28. Ford ES, Giles WH, Myers GL, Rifai N, Ridker PM, Mannino DM. C-reactive protein concentration distribution among US children and young adults: findings from the National Health and Nutrition Examination Survey, 1999-2000. Clin Chem 2003;49:1353-7. 
29. Hutchinson WL, Koenig W, Frohlich M, Sund M, Lowe GD, Pepys MB. Immunoradiometric assay of circulating C-reactive protein: age-related values in the adult general population. Clin Chem 2000;46:934-8.

30. Haverkate F, Thompson SG, Pyke SD, Gallimore JR, Pepys MB. Production of Creactive protein and risk of coronary events in stable and unstable angina. European Concerted Action on Thrombosis and Disabilities Angina Pectoris Study Group. Lancet 1997;349:462-6.

31. Lyngbaek S, Sehestedt T, Marott JL, Hansen TW, Olsen MH, Andersen O et al. CRP and suPAR are differently related to anthropometry and subclinical organ damage. Int J Cardiol 2013;167:781-5.

32. Chun HY, Chung JW, Kim HA, Yun JM, Jeon JY, Ye YM et al. Cytokine IL-6 and IL-10 as biomarkers in systemic lupus erythematosus. J Clin Immunol 2007;27:461-6.

33. Williams RC, Jr., Harmon ME, Burlingame R, Du Clos TW. Studies of serum Creactive protein in systemic lupus erythematosus. J Rheumatol 2005;32:454-61.

34. Lacki JK, Samborski W, Mackiewicz SH. Interleukin-10 and interleukin-6 in lupus erythematosus and rheumatoid arthritis, correlations with acute phase proteins. Clin Rheumatol 1997;16:275-8.

35. ter Borg EJ, Horst G, Limburg PC, van Rijswijk MH, Kallenberg CG. C-reactive protein levels during disease exacerbations and infections in systemic lupus erythematosus: a prospective longitudinal study. J Rheumatol 1990;17:1642-8.

36. Kirou KA, Lee C, George S, Louca K, Peterson MG, Crow MK. Activation of the interferon-alpha pathway identifies a subgroup of systemic lupus erythematosus patients with distinct serologic features and active disease. Arthritis Rheum 2005;52:1491-503.

37. Feng X, Wu H, Grossman JM, Hanvivadhanakul P, FitzGerald JD, Park GS et al. Association of increased interferon-inducible gene expression with disease activity and lupus nephritis in patients with systemic lupus erythematosus. Arthritis Rheum 2006;54:2951-62.

38. Baechler EC, Batliwalla FM, Karypis G, Gaffney PM, Ortmann WA, Espe KJ et al. Interferon-inducible gene expression signature in peripheral blood cells of patients with severe lupus. Proc Natl Acad Sci U S A 2003;100:2610-5.

39. Mold C, Gewurz H, Du Clos TW. Regulation of complement activation by C-reactive protein. Immunopharmacology 1999;42:23-30.

40. Rodriguez W, Mold C, Kataranovski M, Hutt JA, Marnell LL, Verbeek JS et al. Creactive protein-mediated suppression of nephrotoxic nephritis: role of macrophages, complement, and Fcgamma receptors. J Immunol 2007;178:530-8.

41. Rodriguez W, Mold C, Marnell LL, Hutt J, Silverman GJ, Tran D et al. Prevention and reversal of nephritis in MRL/lpr mice with a single injection of C-reactive protein. Arthritis Rheum 2006;54:325-35.

42. Szalai AJ, Weaver CT, McCrory MA, van Ginkel FW, Reiman RM, Kearney JF et al. Delayed lupus onset in (NZB x NZW)F1 mice expressing a human C-reactive protein transgene. Arthritis Rheum 2003;48:1602-11. 
43. Carlucci F, Terence Cook H, Garg A, Pepys MB, Botto M. Lack of effect of a single injection of human C-reactive protein on murine lupus or nephrotoxic nephritis. Arthritis Rheum 2010;62:245-9.

44. Mold C, Du Clos TW. C-reactive protein inhibits plasmacytoid dendritic cell interferon responses to autoantibody immune complexes. Arthritis Rheum 2013;65:1891-901.

45. Shih PB, Manzi S, Shaw P, Kenney M, Kao AH, Bontempo F et al. Genetic Variation in C-Reactive Protein (CRP) Gene May Be Associated with Risk of Systemic Lupus Erythematosus and CRP Concentrations. J Rheumatol 2008;35:2171-8.

46. Kim HA, Chun HY, Kim SH, Park HS, Suh CH. C-reactive protein gene polymorphisms in disease susceptibility and clinical manifestations of Korean systemic lupus erythematosus. J Rheumatol 2009;36:2238-43.

47. Szalai AJ, McCrory MA, Cooper GS, Wu J, Kimberly RP. Association between baseline levels of C-reactive protein (CRP) and a dinucleotide repeat polymorphism in the intron of the CRP gene. Genes Immun 2002;3:14-9.

48. Verzilli C, Shah T, Casas JP, Chapman J, Sandhu M, Debenham SL et al. Bayesian meta-analysis of genetic association studies with different sets of markers. Am J Hum Genet 2008;82:859-72.

49. Kim HA, Jeon JY, An JM, Koh BR, Suh CH. C-reactive Protein Is a More Sensitive and Specific Marker for Diagnosing Bacterial Infections in Systemic Lupus Erythematosus Compared to S100A8/A9 and Procalcitonin. J Rheumatol 2012.

50. Vigushin DM, Pepys MB, Hawkins PN. Metabolic and scintigraphic studies of radioiodinated human C-reactive protein in health and disease. J Clin Invest 1993;91:1351-7.

51. Sjöwall C, Bengtsson AA, Sturfelt G, Skogh T. Serum levels of autoantibodies against monomeric $\mathrm{C}$-reactive protein are correlated with disease activity in systemic lupus erythematosus. Arthritis Res Ther 2004;6:R87-94. 
Table 1. Baseline characteristics of the SLE patients $(n=155)$

\begin{tabular}{|c|c|}
\hline Characteristics & Mean (range) \\
\hline ACR criteria fulfilled (n) & $5.1(4-9)$ \\
\hline SLICC/ACR damage index (score) & $1.2(0-9)$ \\
\hline SLEDAI-2K (score) & $2.5(0-16)$ \\
\hline Disease duration (years) & $11.5(0-45)$ \\
\hline Age (years) & $49.9(18-88)$ \\
\hline Body mass index & $26.1(17.5-48.7)$ \\
\hline Prednisolone dose (mg/day) & $5.1(0-60)$ \\
\hline ACR criteria & $\mathrm{n}(\%)$ \\
\hline 1. Malar rash & $79(51.0)$ \\
\hline 2. Discoid rash & $31(20.0)$ \\
\hline 3. Photosensitivity & $93(60.0)$ \\
\hline 4. Oral ulcers & $17(11.0)$ \\
\hline 5. Arthritis & $120(77.4)$ \\
\hline 6. Serositis & $62(40.0)$ \\
\hline 7. Renal disorder & $41(26.5)$ \\
\hline 8. Neurologic disorder & $10(6.5)$ \\
\hline 9. Hematologic disorder & $97(62.6)$ \\
\hline 10. Immunologic disorder & $81(52.3)$ \\
\hline 11. Antinuclear antibody* & $152(98.1)$ \\
\hline
\end{tabular}

*Analyzed with immunofluorescence microscopy. ACR = American College of

Rheumatology, SLICC = Systemic Lupus International Collaborating Clinics, SLEDAI-2K = Systemic Lupus Erythematosus Disease Activity Index 2000. 
Table 2. Association of $C R P$ polymorphism rs1205 with CRP levels

\begin{tabular}{lccc}
\hline rs1205 Genotype & Patients (n) & Median CRP (mg/L) & p-value* \\
\hline GG & 73 & 2.63 & 0.045 \\
GA & 65 & 2.14 & \\
AA & 17 & 1.13 & \\
*Mann-Whitney (comparing GG versus GA and AA). CRP = C-reactive protein.
\end{tabular}

Table 3. Association of SLEDAI-2K and IL-6 with $\log C R P$

\begin{tabular}{lccccc}
\hline Patient selection & $\mathrm{n}$ & \multicolumn{2}{c}{ SLEDAI-2K } & \multicolumn{2}{c}{ IL-6 } \\
& & p-value & Beta & p-value & Beta \\
\cline { 4 - 6 } 1. All patients & 155 & 0.2 & 0.9 & \\
2. IFN $<1 \mathrm{U} / \mathrm{mL}$ & 119 & 0.1 & 0.001 & 0.29 \\
3. rs1205 major alleles* & 73 & 0.005 & 0.33 & 0.001 & 0.37 \\
4. Combination of 2 and 3 & 57 & $<0.0005$ & 0.52 & 0.001 & 0.41 \\
\hline
\end{tabular}

*Homozygous for the major allele (G). P-values and standardized beta coefficient (Beta) are from a multiple linear regression analysis adjusting for age and body mass index. CRP = C-reactive protein, SLEDAI-2K = Systemic Lupus Erythematosus Disease Activity Index 2000, IFN = Interferon, IL = Interleukin. 


\section{FIGURE}

A

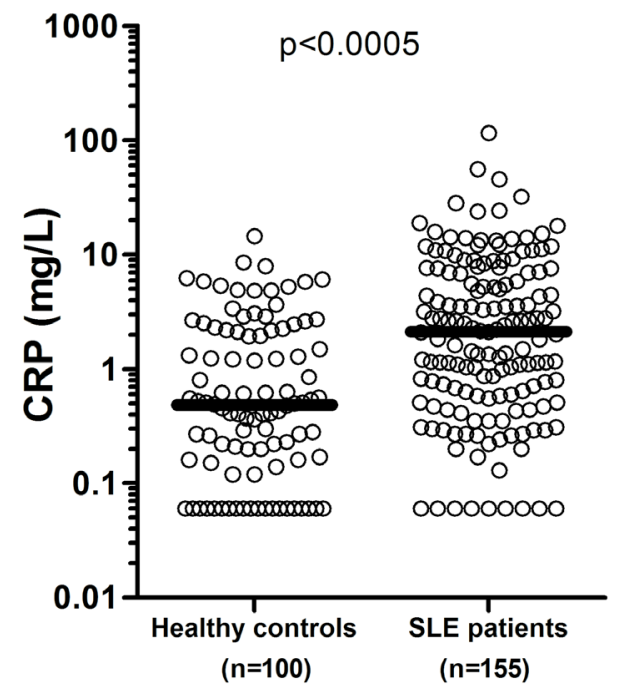

B

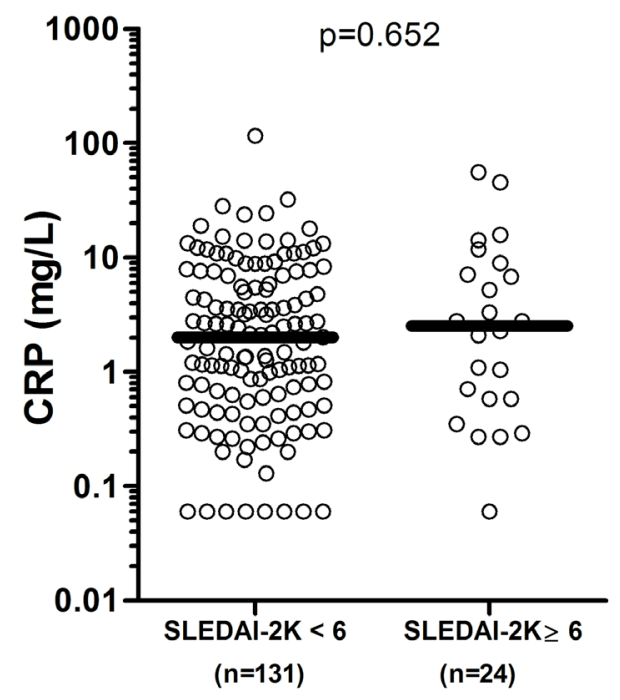

Figure 1. Serum levels of C-reactive protein (CRP) in healthy controls and systemic lupus erythematosus (SLE) patients. (A) SLE patients had significantly higher levels of CRP compared to healthy controls, (B) but there was no significant difference in CRP comparing patients with active disease (SLE disease activity index, SLEDAI $\geq 6$ ), with patients with low/no disease activity (SLEDAI $<6$ ). Bars represent median values. 